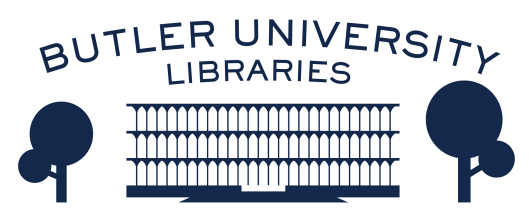

Journal of Hindu-Christian Studies

Volume 18

Article 14

January 2005

\title{
Book Review: "Siva in the Forest of Pines: An Essay on Sorcery and Self-Knowledge"
}

Anand Amaladass

Follow this and additional works at: https://digitalcommons.butler.edu/jhcs

Part of the Religion Commons

\section{Recommended Citation}

Amaladass, Anand (2005) "Book Review: "Siva in the Forest of Pines: An Essay on Sorcery and SelfKnowledge"," Journal of Hindu-Christian Studies: Vol. 18, Article 14.

Available at: https://doi.org/10.7825/2164-6279.1347

The Journal of Hindu-Christian Studies is a publication of the Society for Hindu-Christian Studies. The digital version is made available by Digital Commons @ Butler University. For questions about the Journal or the Society, please contact cbauman@butler.edu. For more information about Digital Commons @ Butler University, please contact digitalscholarship@butler.edu. 


\title{
BOOK REVIEWS
}

\author{
Siva in the Forest of Pines: An Essay on Sorcery and Self- \\ Knowledge. Don Handelman and David Shulman. New Delhi: \\ Oxford University Press, 2004, xii +246 pp.
}

THIS book is a companion volume to the previous work God Inside out: Siva's Game of Dice (1997), as the authors mention at the beginning. The episode of the Daruvana from the vast mythology about Siva is the theme of this volume, and it provides scope for sustained interpretation by the authors. They translate the concerned section of the Tamil version of the myth recorded at three major temple sites - Kancipuram, Cidambaram, and Tiruelveli. Besides their translation they have also written a commentary on the texts.

David Shulman is a scholar well known from his earlier work Tamil Temple Myths (1980), and now he is teaming with other colleagues to go into the Saiva tradition, as it is handed down in the South Indian temple myths. It is creditable that they look into these texts and bring to light what would otherwise remain hidden from the Western world. Writing commentary is not the strength of the Saivite community compared to the rich Vaishnava tradition. Perhaps this sort of publication would initiate a new trend of writing commentary on Siva in modern times.

The story related to the pine forest itself is well known. Siva's visit to Daruvana accompanied by Vishnu as Mohini, their erotic dancing to entice the sages and their wives give scope for the imagination of the writers and the commentators to elaborate on it at length, even if the purpose of the myth is not clearly spelled out by these commentators. Why this episode among many others about Siva is by and large popular and has thus drawn the attention of the Western scholarship could be subjective bias. Siva is the Lord of contradiction and everything could be said about him, since he integrates all humanly opposing attributes.

However it not clear what the authors want to achieve by the type of analysis they bring to the text. Is it to bring some coherence into Saiva theology by harmonising the different versions of this episode, or is it to heighten the awareness of Siva's presence among Saiva followers? The type of language they use and the sophisticated epistemology they bring in to explain Siva's visit to the pine forest would rather leave the followers of Siva cold, if not puzzled, as they tease out the text's meaning. The reader is told to dispense with the commentaries if $s / h e$ wants to read only the texts.

The authors go into particular detail in analyzing Tamil and Sanskrit terms in the Saivite context. However a few of their observations in this regard are worth highlighting. For instance, their analysis of the Tamil word "Arul" is curious. They find it unfortunate to translate this critical term as "grace", with its heavy Christian connotations. (p.41) It is not "grace", but "emergent presence" (42), "God's coming into presence, a ritual effect "(62), "fullness of presence" (84). In the Judeo-Christian context "grace" emphasizes the "gift" aspect, what is freely given, gratuitous, not merited etc. But the Indian terms, even the Sanskrit "prasada" (clarity, transparency), emphasize the consequence of receiving the "gift", the gifted moment wherein one "sees clearly". Both the traditions do not intend an exclusive sense. Both these aspects are implied, even though they make thematic only one of them. So it would be also a Semitic bias to leave out this nuance of grace to the Tamil word "Arul" in the Saivite context. The hymns of the Saiva saints were born out of grace, 
and the bhaktas are all longing for the grace of the Lord Siva.

Another curious term used by the authors here in the Saiva context is sorcery or black magic. They find a Sanskrit term "abhicara" for it and the Kanta Purnaa text refers to it as "velvi" (p.88). The use of the term "sorcery" with all its negative connotations in the context of the Daruvana episode is rather misleading. The traditional understanding of the yogic powers which are creative and Siva's creative power to transform all obstacles are not sorcery. It is not clear why the authors hesitate to call it "miraculous power", a term well known in the religious literature of the world. Sorcery, witchcraft and "pillicunyam" (Tamil equivalent), terms which would sound very odd in the Judeo-Christian context, have their own logic and ontology, as the authors point out (p.90). But then what they describe after that is the creative process of phenomenal existence and the formation of the individual consciousness. Yet one wonders how this analysis fits into the visit of Siva to the pine forest.

It may be true that the Saiva theologians' conceptual world is rigid, static, strangely idealistic. But then they are not used to interacting with process theologians. Perhaps an initiation into process theism might bring some fresh thinking to the Saiva worldview. However the standard objections of the Christian theologians to this approach will hold good also for the Saiva understanding of the divine. A statement like this: Siva "though omniscient, there are many things he does not know - every thing that has to do with non-sentient phenomena for example," (p.200) would also imply a limited understanding of God's transcendence.

The authors' effort to get at this Daruvana episode by way of process theism requires careful study and theological insight. I hope this publication invites Saivite thinkers to respond to this type of theological interpretation and look at their own tradition from a new angle, even if they do not accept it fully. Such an intercultural exchange would be fruitful to both sides of the dialogue. Otherwise the Siva episodes will remain mere stories in calendar art and repeated with usual clichés without enriching the tradition.

Anand Amaladass Chennai

\section{A History of Modern Yoga: Patanjali and Western Esotericism. Elizabeth De Michelis. New York: Continuum, 2004, xvii +282 pp.}

IN his important book, The Limits of Scripture, Anantanand Rambachan distinguishes between Sankara and Vivekananda on the authority of the Vedas and its relationship to anubhava or personal experience. Now in her $A$ History of Modern Yoga, De Michelis shows how a similar distinction obtains between Patanjali's Yoga Sutras and Vivekananda's Raja Yoga. Further, she demonstrates how this reinterpretation of Yoga by Vivekananda depends on Keshubchandra Sen's earlier "revivalistic reinterpretation" of Yoga (p. 84) and how Vivekananda's Raja Yoga is foundational for the various developments of Modern Yoga which take place in the English-speaking world during the twentieth century. A historical analysis and "Typology of Modern Yoga" is developed, and as a criterion example of Modern Yoga, a detailed, case study of the theory and practice of lyengar Yoga is offered.

All of this is most helpful in allowing one to sort out and understand the plethora of Modern Yoga schools, 